\title{
Gender and Performance Expectancy of Agriculture Teachers towards ICT Integration in Swaziland
}

\author{
Mzomba Nelson Dludlu and Nomsa Mndzebele
}

\begin{abstract}
The purpose of the study was to describe gender and performance expectancy of agriculture teachers towards ICT integration in teaching secondary school agriculture in Swaziland. The study was a descriptive correlational study employing quantitative approach in data collection. A census of 314 agriculture teachers was a target population for the study and 284 responded to the questionnaires that were used to collect data. Descriptive statistics and correlations were used to analyse data. Findings revealed a negligible to low positive association between gender and performance expectancy of agriculture teachers towards ICT integration in teaching secondary school agriculture. There was no significant difference between male and female agriculture teachers in their performance expectancy towards ICT integration in teaching. The ICT integration competency possessed by agriculture teachers has contributed to positive perception and usefulness in job performance. It was recommended that teacher education institutions should be informed to include ICT integration in teaching as a major component of instructional delivery strategy so that both male and female teachers are competent when they graduate.
\end{abstract}

Index Terms-Gender, ICT integration and performance expectancy.

\section{INTRODUCTION}

The rapid growth in Information and Communication Technology (ICT) has brought remarkable changes in the $21^{\text {st }}$ century, and has also affected the demands of modern societies. ICT is becoming increasingly important in people's daily lives and educational system. Therefore, there is a growing demand on educational institutions to use ICT to teach the skills and knowledge [1]. The global integration of ICT into education has often been premised on the potential of the new technological tools to revolutionize an outmoded educational system, better prepare students for the information age, and accelerate national development efforts. [2] State that while developed countries have reported up to $41 \%$ integration of ICT into teaching and learning, the proportion remains substantially low in Africa, Swaziland included [2]. The "teacher talk" approach in teaching agriculture is dominant in secondary schools with limited use of available ICT tools that would allow learners to construct their own knowledge. School leaders and teachers must have enough awareness about the importance of ICT as a catalyst to facilitate teaching-learning process [3].

Manuscript received August 23, 2017; revised November 14, 2017.

Mzomba Neslson Dludlu is with Ngwane Teachers Training College, Swaziland (e-mail: mzomba43@gmail.com).

Nomsa Mndzebele is with the Business Administration Department, Faculty of Commerce, University of Swaziland, Swaziland (e-mail: nomsa@uniswa.sz).
Ref. [4] observed that one of the targets of the Ministry of Education and Training towards ICT introduction was to ensure that $70 \%$ of schools will have computer laboratories with internet access and qualified teachers. Ref. [5] reported that ICTs such as computers/internet were mainly used for office applications (word-processing, spreadsheets) by females than males among teachers and students. ICT has been integrated into many chemistry courses and shown educational benefits by changing from the traditional teaching to using ICT [6]. For successful integration of new technologies and ICT, teachers need to have high proficiency in pedagogical as well as agriculture knowledge.

Technology should be integrated into teacher preparatory programmes so that agriculture teachers can see technology in use [7]. This in turn will influence the way they use technology when they become field teachers. Agricultural education teacher preparatory programme is increasingly characterised by high enrolment of females as opposed to the past. In Swaziland, the use of technology in teaching has been associated with male teachers as opposed to the female teachers. The study is therefore conducted to find out if there is a relationship between performance expectancy and gender of agriculture teachers towards ICT integration in teaching Secondary School Agriculture curriculum in Swaziland. Teachers integrate the technology into their teaching methods, curriculum, to enrich the learning experiences of their students. They select, drill and practice software based on curricular goals and needs of their students. In addition, they introduce a broad range of computer applications and developed creative and engaging projects that blend computer activities with adequate instruction [8].

Ref. [9] outlined different technologies and forms of ICT services available and usable in schools to facilitate the teaching and learning of agriculture. The results of the study showed that ICT service was available through spreadsheet, power point presentation, typing agricultural science notes, communication, preparing teaching time table, using word processing, accessing internet, developing and publishing information, and searching for research articles.

\section{PERFormance EXPECTANCY}

Ref. [10] defined performance expectancy as the degree to which an individual believes that using the system would help him or her to attain gains in job performance. Ref. [11] reported that performance expectancy had a significant influence on technology acceptance. In a study that applied the Unified Theory of Acceptance and Use of Technology (UTAUT) to analyze students' ICT adoption, performance expectancy was found to be the strongest predictor of 
intention. [12] Argued that performance expectancy exerted the strongest effect.Therefore, it seems that this is the most influencial factor for the acceptance and use of ICT by teachers. The predictive effect of performance expectancy was mediated by age, gender, and experience. The findings further indicated that at an early age there was no significant difference in interest shown by boys and girls in using computers. However, girls' interest wanes later on.

\section{GENDER AND ICT USE}

There are mixed findings about gender and its effect on ICT use in teaching. [13] States that gender plays a role in teacher's use of ICT in teaching whiles [14] have established that there is a non-significance influence of teacher's demographics in terms of gender on teachers ICT use.

Gender moderates performance expectance, and social influence. Men tend to have higher performance expectancy than women because they are inclined to be task-oriented and task achievement is improtant to them. This instinct derives from gender roles and socialization. As for social influence, women tend to be more sensitive to others' $\mathrm{s}$ opinions than men so that social influence is more salient in adopting technology to women than men [15]. Ref. [16] reported gender as a very influencing factor on ICT use. They reported that there is a gender digital devide, as a result of high versus low literacy, high versus low income and rural urban devide. According to [17] and [16] men are more receptive to ICT use than women which means that male teachers are more receptive to ICT use than female teachers. Research findings on gender gap have show that female teachers differ in terms of ICT use [18].

Ref. [19] reported that gender is an influencing factor in ICT use. Ref. [17] states that it could be that females are preoccupied with other issues thus do not have time to use ICT facilities. Ref [20] state that there is no relationship between ICT use in teaching and gender. However, there is a relationship between teaching experience and the uses of ICT. Teachers that have been teaching for some time tend to be reluctant to use ICT. The higher the teachers experience the more reluctant the use of ICT, which implies that the younger teachers are the ones who are using ICT in the classroom. [21] Found that there is no difference between highly experienced and less experienced teachers use of ICT in the learning environment. Technology Acceptance Model (TAM) posits that acceptance and use of ICT depend on an individual's perceptions of the usefulness and ease of use of the technology [22].

\section{Methodology}

The design of the study was a descriptive survey employing a quantitative approach in data collection. Closed ended questionnaires were used to collect data. The target population for the study was secondary agriculture teachers ( $N=314)$. A Census study was done, therefore, all agriculture teachers, both Modern and Pre-Vocational, were included in the study. A survey questionnaire was developed guided by the Unified theory of acceptance and use of technology (UTAUT) and employed. Cronbach's alpha internal consistency reliability computed yielding a coefficients $\mathrm{r}=$. 80. The response rate from agriculture teachers was $90.4 \%(N=284)$. Data were collected by hand delivering the questionnaires to the respondents in all the four regions of the country Swaziland. Descriptive statistics and correlations were used to analyse data. T-test statistic was computed to identify if there were any significant differences between male and female agriculture teachers in performance expectancy towards ICT integration in teaching secondary school agriculture.

\section{FINDINGS}

Performance expectancy and gender: Findings in Table I indicated that a negligible to low association existed between gender and performance expectancy of agriculture teachers towards ICT integration in teaching. The domain values were: awareness $(r=04)$; relative advantage $(r=.13)$; motivation $(r$ $=.09)$; and attitude $(r=.05)$.

Table II shows findings of independent t-test on gender and performance expectancy of agriculture teachers towards ICT integration in teaching. Findings revealed that there was no significant difference in performance expectancy between male and female agriculture teachers.

TABLE I: RELATIONSHIP BETWEEN PERFORMANCE EXPECTANCY AND GENDER $(N=284)$

\begin{tabular}{ll}
\hline $\begin{array}{l}\text { Performance } \\
\text { expectancy }\end{array}$ & Correlation coefficients $(\mathrm{r})$ \\
\hline Relative & .13 \\
advantage & .09 \\
Motivation & .05 \\
Attitude & .04 \\
Awareness & .04 \\
\hline
\end{tabular}

Rating scale: $1=$ Strongly Disagree; 2 = disagree; 3 = Slightly disagree; $4=$ Slightly agree; 5 = Agree; $6=$ strongly agree

TABLE II: T-TEST ON GENDER AND PERFORMANCE EXPECTANCY $(N=284)$

\begin{tabular}{lllllll}
\hline Variable & Gen & $\mathrm{N}$ & $\mathrm{M}$ & $\mathrm{Std}$ dev & $\mathrm{F}$ & $\mathrm{Sig}$ \\
\hline Awareness & $\mathrm{F}$ & 94 & 5.3457 & .66 & .168 & .682 \\
& $\mathrm{M}$ & 190 & 5.4026 & .64 & & \\
Relative & $\mathrm{F}$ & 94 & 4.9723 & .75 & .135 & .714 \\
advantage & & & & & & \\
& $\mathrm{M}$ & 190 & 5.2484 & 1.12 & & \\
Motivation & $\mathrm{F}$ & 94 & 4.5816 & .70 & .171 & .679 \\
& $\mathrm{M}$ & 189 & 4.7754 & 1.04 & & \\
Attitude & $\mathrm{F}$ & 94 & 5.2383 & .63 & .377 & .540 \\
& $\mathrm{M}$ & 94 & 5.3568 & 1.21 & & \\
\hline
\end{tabular}

Rating scale: $1=$ Strongly Disagree; 2 = disagree; 3 = Slightly disagree; $4=$ Slightly agree; 5 = Agree; $6=$ strongly agree

Relationship between Performance expectancy and gender towards ICT integration: Findings illustrate negligible to low positive association between gender and performance expectancy towards ICT integration in teaching: relative advantage, motivation, attitudes, and awareness.

\section{CONCLUSION}

The design study was descriptive survey using a quantitative approach. Close ended questionnaires were sent to participants both male and female. A survey questionnaire 
was developed guided by the unified theory of acceptance. Drawing from the findings, both male and female agriculture teachers can use ICT integration resources without any problem. They both can tap the benefits of ICT integration in teaching and its outcomes can be compared. This finding suggests the adoption of ICT integration in teaching agriculture as an instructional delivery strategy in secondary schools can be achieved with equal measure. That is to say the new approach can be adopted without considering gender as a bearer.

Male and female agriculture teachers especially the younger cohorts have received adequate exposure to ICT integration teaching and learning and this makes them some-what competent users of technology in instructional delivery. The pre-service teacher preparatory programme for agriculture education offers adequate learning experiences for the graduates. The programme has made agriculture teachers to possess a competitive advantage over other teachers in secondary schools in ICT integration as instructional delivery strategy. The ICT integration competency possessed by agriculture teachers has contributed to the positive perception and usefulness in job performance.

The challenges that still exist is that the older cohort of agriculture teachers who still believe in traditional instructional technologies of teaching are still teaching. The schools hope that they would retire leaving only the younger generation in the practice. A high rate of adoption of new approaches and innovations to teaching is expected among the younger generation of teachers.

It is recommended that pre-service teacher education institutions should be informed to include ICT integration in teaching as a major component. Learners, both male and female who enroll in teacher training institutions are relatively young in age thus are likely to benefit and become more competent practitioners in ICT integration.

\section{REFERENCES}

[1] C. B. Andoh, "Factors information and communication technology into teaching: a review of the literature," International Journal of Education and Development Using Information and Communication Technology, vol. 8, no. 1, 137-158, 2012.

[2] D. M. Nchunge, M. Sakwa, and W. Mwangi, "Assessment of ICT infrastructure on ICT adoption in educational institutions: A descriptive survey of secondary schools in Kiambu County Kenya," Journal of Computer Science and Information Technology, pp. 32-45, 2013.

[3] A. B. Tedla, "Understanding the importance, impacts and barriers of ICT on teaching and learning in East African Countries," International Journal for e-Learning security, vol. 2, no. 3, pp. 199-207, 2012.

[4] M. Ntshangase, "Draft policy for information and communication technology in education," Ministry of Education and Training, Mbabane, Swaziland, 2010.

[5] T. Shongwe, "The national information and communication infrastructure policy," Kingdom of Swaziland, Mbabane, 2012.

[6] M. Barak, "Purposely teaching for the promotion of higher-order thinking skills: A case of critical thinking," Research in Science Education, vol. 37, no. 4, pp. 353-69, 2007.

[7] S. Hennessy, K. Ruthven, and S. Brindley, "Teacher perspectives on integrating ICT into subject teaching: Commitment, constraints, caution and change," Journal of Curriculum Studies, vol. 37, pp. 155-192, 2005.

[8] S. Muntaz, "Factors affecting teachers' use of information and communication technology: a review of the literature," Journal of Information Technology for Teacher Education, vol. 9, no. 3, pp. 319-342, 2006.

[9] K. Hulela, K. Rammolai, and W. Mpatane, "Assessment of computer technology available, accessibility and usable by agricultural education students teachers in secondary schools in Botswana," Journal of Education Research and Reviews, vol. 9, no. 17, pp. 610-617, 2014.

[10] S. N. Attuquayefio and H. Addo, "Using the UTAUT model to analyse students' ICT adoption," International Journal of Educational Development Using Information and Communication Technology, no. 3, pp. 75-86, 2014.

[11] C. Liu and K. Kostiwa, "An application of the UTAUT model for understanding student perceptions using course management software," Journal of Educational Technology and Society, vol. 7, no. 2, pp. 93-104, 2013.

[12] N. D. Oye, A. N. Iahad, and N. Z Rahim, "A model of ICT acceptance and use for teachers in higher education," International Journal of Computer Science and Communication Networks, vol. 1, no. 1, pp. 22-40, 2011.

[13] E. Tezci, "Teachers effects on ICT use in education: the Turkey sample," Procedia-Social and Behavioral Sciences, vol. 1, no. 1, pp. 1285-1294, 2009.

[14] S. Sabariah and O. Khaziyati, "Teachers perception on professional development needs in information and communication technology (ICT)," Terengganu: Persatuan Teknologi Pendidikan Malaysia.

[15] V. Venkatesh and F. D. Davis, "A theoretical extension of the technology acceptance model: Four longitudinal field studies," Management Sciences, vol. 45, no. 2, pp. 186-204, 2000.

[16] K. A. Aramide, S. O. Lapido, and I. Adebayo, "Demographic variables and ICT access as predictors of information communication technologies' usage among science teachers in federal unity schools in Nigeria," Library Philosophy and Practice (e journal), 2015.

[17] J. A. Idoko and A. Ademu, "The challenges of informatio and communication technology for teaching — Learning as perceived by Agricultural science teachers in secondary schools in Kogi state," Journal of Educational Innovators, vol. 3, no. 2, pp. 43-49, 2010.

[18] A. Mitra, "Gender and computer use in academic institution, report from a longitudinal study," Journal of Education Computing Research, vol. 23, no. 1, pp. 67-84, 2001.

[19] R. A. Olatoye, "Effect of further mathematics on students achievement inmathematics, biology, chemistry and physics," International Journal of Environmental and Science Education, vol. 2 no. 2, pp. 48-5, 2007.

[20] M. Rahimi and S. Yadollahi, "Computer anxiety and ICT integration in English classes among Irania EFL teachers," Procedia Computer Science, vol. 3, pp. 203-209, 2011.

[21] D. S. Niederhauser and T. Stoddart, "Teachers instructional perspectives and use of educational software," Teaching and Teacher Education, vol. 17, no. 1, pp. 15-31, 2001.

[22] F. Davis, "Perceived usefulness, perceived ease of use, and user acceptance of information technology," MIS Quarterly, vol. 13, no. 3, pp. 319-340, 1989.

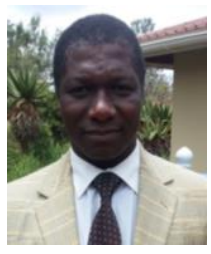

Mzomba Nelson Dludlu is currently a vice prcincipal at Ngwane Teachers Training College in Swaziland. He has served as high school head teacher for 9 years 2005-2013. In 2014 he became a vice principal at William Pitcher College.

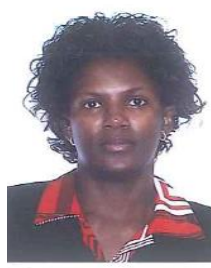

N. Mndzebele achieved the bachelor of commerce major in accounting, at University of Swaziland and got an MBA in CALPOLY in California, USA and the PhD in information systems in UKZN South Africa. Has worked in industry and now teaching since 1992. 